\title{
EFFECT OF FOOD HABITS AND NUTRITIONAL AWARENESS ON BODY MASS INDEX AND HEALTH STATUS AMONG GIRLS ADOLESCENTS OF INTERMEDIATE SCHOOLS IN MADINAH MUNAWARAH
}

\author{
By \\ Eman Sobhy Taha Attia \\ Suha Hashem Abduljawad \\ Food Science Dept., Faculty of Family Food Science Dept., Faculty of Family \\ Sciences, Taibah University, Madinah Sciences, Taibah University, Madinah \\ Munawarah, KSA. \\ Munawarah, KSA. \\ National Nutrition Institute (NNI), \\ Cairo.
}

Research Gournal Specific Fducation

Faculty of Specific Fducation

SMansoura University

ISSUE NO. 38, APRIL. 2015

$$
\text { مجلة بحوث التوبية النوعية - جامعة المنصورة }
$$




\title{
EFFECT OF FOOD HABITS AND NUTRITIONAL AWARENESS ON BODY MASS INDEX and Health Status among GIRLS Adolescents Of INTERMEdiate SCHOOLS IN MADINAH MUNAWARAH
}

\author{
Eman Sobhy Taha Attia* \\ Suha Hashem Abduljawad ${ }^{* * *}$
}

Abstract

Background: Adolescence is defined by the World Health Organization as the period between childhood and adulthood, spanning from 10 to 19 years of age. Adolescence is a time of increased growth and development, in which a greater need for nutrients coincides with a change in food habits that also influences nutritional needs. Due to differences in body type, physical activity, and rate of growth, every adolescent has different nutritional needs.Objective: The present study aims to assess food habits and nutritional awareness for girls Adolescents and describes its relation with body mass index and health status and socio-demographic differentials. Methodology: This study was carried out on 300 girls Adolescents aged 12 to 17 years were chosen from 32 intermediate schools Al Madinah Al Munawwarah, KSA. Data socioeconomic status, health history, food habits, anthropometric measurements and, Nutritional awareness were collected. Results: The mean value of age was $14.33 \pm 1.11$ years, the mean value of length was $150.86 \pm 5.58 \mathrm{~cm}$, the mean of arm circumference was $24.33 \pm 2.71 \mathrm{~cm}$ and the mean value of weight was 47.71 $\pm 10.86 \mathrm{~kg}$. Also the result showed that $11.7 \%$ of studied girls were suffering from overweight, while the most of girls had normal weight $52.0 \%$, the mean value of body mass index mean was $20.82 \pm 4.12 \mathrm{~kg} / \mathrm{m} 2$. Most of girls $84.3 \%$ were no suffering from diseases, while about $15.7 \%$ of girls were suffering from diseases including; anemia, tuberculosis, diabetes

Food Science Dept., Faculty of Family Sciences, Taibah University, Madinah Munawarah, KSA.

${ }^{* *}$ National Nutrition Institute (NNI), Cairo. 
mellitus. As for bad dietary habits were like eating one meal per day, delete the breakfast, and low rates of milk consumption, meat and fruits and vegetables daily. The nutritional awareness degree were classified into three degrees; of the categories; awareness is low (less than 60\%), awareness is intermediate (greater than $60 \%-79.9 \%$ ), awareness is high ( $80 \%$ or more), the nutritional awareness level in the study sample, the most of girls 52.5\% have middle level of awareness, while $38.1 \%$ of them have high level of awareness, and finally $9.4 \%$ of them have low level of dietary awareness,. There was a statistically significant relationship between nutritional awareness degree and health status at $(\mathrm{P}<0.01)$, also there was a statistically significant relationship between nutritional awareness degree and anthropometric measurements (weight, body mass index). In conclusion: High percentage of girls adolescents hade a middle degree of $d$ nutritional awareness This study recommended to the importance of raising awareness of food among teenagers, because of its positive effects to change some beliefs and habits inherited misconceptions. Stay nutrition education workshops for teenagers diet patrol through the institutions concerned.

Keywords: Food habits, nutritional awareness, , body mass index , adolescence, intermediate schools.

\section{NTRODUCTION}

Adolescent is defined by WHO as a person between 10-19 years of age. There are about 1.2 billion adolescents worldwide and one in every five people in the world is an adolescent (WHO, 2007). Adolescence is a crucial period for healthy development in both psychological and physical terms. It is a stage of development transition, i.e. a bridge between childhood and adulthood. It is the stage of development of adult mental process and about adult identity and transition from total socio-economic dependent to relative independent. The WHO has defined adolescence as:- a) Progression from appearance of secondary sex characteristics (puberty) to sexual and 
reproductive maturity. b) Development of adult mental processes and adult identity. (Shirur, 2000).

The transition from childhood into adolescence often results in diets becoming less healthy. An unhealthy diet during adolescence can negatively affect growth and development, and is likely to persist into adulthood (Haerens et al., 2008). The phenomenal growth that occurs in adolescence, second only to that in the first year of life, creates increased demands for energy and nutrients. Total nutrient needs are higher during adolescence than any other time in the lifecycle (Forbes, 1992).

Nutrition and physical growth are integrally related; optimal nutrition is a requisite for achieving full growth potential.1 Failure to consume an adequate diet at this time can result in delayed sexual maturation and can arrest or slow linear growth (Story, 1992). Nutrition is also important during this time to help prevent adult diet-related chronic diseases, such as cardiovascular disease, cancer, and osteoporosis. Prior to puberty, nutrient needs are similar for boys and girls. It is during puberty that body composition and biologic changes (e.g., menarche) emerge which affect gender-specific nutrient needs (Story, 1992).

Nutrient needs for both males and females increase sharply during adolescence.1 Nutrient needs parallel the rate of growth, with the greatest nutrient demands occurring during the peak velocity of growth. At the peak of the adolescent growth spurt, the nutritional requirements may be twice as high as those of the remaining period of adolescence (Forbes, 1992).

Saudi Arabia has experienced rapid sociocultural changes caused by the dramatic rise in the economy of the Arabian Gulf region. This transformation, associated with major changes in food choices and eating habits, have become increasingly cause of the rising rates of overweight and obesity in the Saudi population (Al-Rethaiaa et al., 2010). The rapid development in the economy that took place in Saudi Arabia during the previous decades, resulted in the adoption of a sedentary lifestyle and 
consumption of high fat and low-fiber diet among adolescents (Abalkhail and Shawky, 2002).

Poor nutrition during any of these stages can have lasting consequences on an adolescent's cognitive development, resulting in decreased learning ability, poor concentration, and impaired school performance (Stang and Story, 2005).

Adolescents spend a good deal of time away from home and many consume fast foods, which are convenient, but are often high in calories and fat. It is common for adolescents to skip meals and snack frequently (Greer FR, Krebs, 2006). Eating fast food (sugar-sweetened beverages, fried potatoes, fried chicken, hamburgers-hot pizza, and salty snacks) was associated with overweight (BMI $\leq 85$ th percentile (Shang et al., 2014). The gradual growth pattern that characterizes early childhood changes to one of rapid growth and development, affecting both physical and psychological aspects of health. Because all of these changes have a direct impact on the nutrient need and dietary behaviors of adolescents, it is important that health care providers develop a full understanding of how these developmental changes of adolescence can affect nutritional status (Mahan and EscottStump , 2008)

\section{AIM OF STUDY}

The study was carried out amongst adolescent Saudi female students of intermediate schools in Madinah, to evaluate food habits as well as nutritional awareness and their impact on health status and anthropometric measurements (Body mass index and weight) to raise their knowledge and motivate their attitude to practice sound nutritional habits.

\section{SUBJECTS AND METHODS}

This study was carried out on 300 adolescent Saudi female students aged 12 to 17 years were chosen from 32 intermediate schools from 5 regions that represent geographical areas (east, west, north, south and middle) in Al Madinah Al Munawwarah, KSA. 


\section{Data Collection:}

Data were collected using self-administered questionnaire consisting of socio-demographic, health history, and dietary habits, anthropometric and blood pressure measurements.

\section{Socioeconomic Status:}

Data about age, education level of fathers and mothers, family size; children in order and family's income were done according to Park and Park, (1979).

\section{Health state}

Data about suffering from diseases, types of disease, taking medications, medications types, and taking dietary supplements were collected.

\section{Food Habits:}

Data about number of meals, eating breakfast, places of eating it, preferred foods and cooking method and some food items consumptions were collected.

\section{Anthropometric Measurements:}

Weight and height were measured with the subjects wearing light clothing, without shoes and were recorded to the nearest $0.1 \mathrm{~kg}$, and $0.1 \mathrm{~cm}$, respectively. Waist circumference was recorded according to Kuczmarski et al (2000).

Body mass index (BMI) and BMI percentiles for age and sex were determined based upon the established World Health Organization international anthropometrical references (WHO, 1995). Underweight in adolescents is defined as a BMI_5th percentile. A normal BMI ranges from the 5th to less than the 85th percentile. Overweight is considered between the 85th to <95th percentile \& obesity as BMI _ 95th percentile (Bellizzi and Dietz, 1999). 


\section{Dietary awareness:}

Data collected to assess knowledge attitude and practice about nutrition among adolescent Saudi female students attending data were collected by personal interview using well-structured questionnaire. It included 20 questions which are about knowledge, attitude towards food, nutrients, healthy diet and prevention of malnutrition. Evaluation done by giving each correct answer 1 and for wrong and don't know score of 0 .

\section{Statistical Analysis:}

Data were analyzed using statistical for social science (SPSS) program, version 16.0. (SPSS, 1998).

\section{Results}

Epidemiological features of the studied sample of adolescent Saudi female students at middle schools were presented in table (1). It was noticed that the mean age of girls student was $14.33 \pm 1.11$ years for; the mean weight $47.71 \pm 10.86$; the mean height was $150.86 \pm 7.45$. The BMI mean was $20.82 \pm 4.12$ and the mean arm circumference was $24.33 \pm 2.71$.

Table (2) shows the percent distribution of female adolescents by weight categories. The incidence of underweight is $28.7 \%$ and normal weight is $52.0 \%$. Also, the combined prevalence of overweight and obesity were $11.7 \%$ and $7.6 \%$ respectively in female adolescents.

Table (3) shows demographic characteristic of the study sample, the total number of study participants amounted to 300 female adolescents; most of them were enrolled at the third grade year $43.7 \%$. Mothers ' Middle / Secondary educations were among females by $37.7 \%$, while father's university education was $34.3 \%$ and $58.5 \%$, respectively. Furthermore, the percentage of working fathers was $61.1 \%$ as government employee, as for working mothers was $66.67 \%$ was unemployed, and the majority of the sample family sizes were $58.30 \%$ from 6 to 9 . Moreover, the majority of students $35.3 \%$ had high family income more 6000 to 10000 Saudi Riyal, while $14.7 \%$ of them had low family income between 1000 to 3000 SR. 
Table (4) shows health state of the study sample, the total number of study participants amounted to 300 female adolescents; $84.3 \%$ of them were not suffering from diseases, while about $15.7 \%$ of them were suffering from diseases $48.90 \%$ of them were suffering from anemia, and $10 \%$ of them were suffering from gastrointestinal diseases, and $8.30 \%$ of them suffering from hypertension, and $6.50 \%$ of them suffering from liver diseases and cardiovascular disease, while $8.30 \%$ of them suffering from diabetes mellitus. As for taking medications, the female adolescents were $74.7 \%$ do $4 \mathrm{t}$ taking medications, while $25.3 \%$ of them were taking different medications, including: $42.20 \%$ were sedatives and $32.70 \%$ were antibiotics, $5.20 \%$ were diabetic drugs, and $2.30 \%$ were hypertension drugs. The same table also illustrates, the female adolescents were $23.7 \%$ do not taking dietary supplements, while $76.3 \%$ of them were taking different dietary supplements.

Table (5) food habits of the study sample, the majority of female adolescents reported eating three meals daily $54 \%$, and about $28.33 \%$ of them reported eating two meals daily, and $9.33 \%$ were eating more than four meals, while $8.34 \%$ of students reported eating one meal per day. The majority of female adolescents reported deleted the breakfast meal about $41.0 \%$, while $16.0 \%$ of them reported delete lunch meal. It is clear from table (5) the majority of girls reported eating breakfast $51.70 \%$, and about $48.30 \%$ of them did not reported eating breakfast. Regarding preferred foods, the majority of girls were preferred soft drinks 33\%, while about $8.3 \%$ of them were preferred nuts. The majority of girls reported drinking tea $70 \%$, and about $30 \%$ of them did not drinking. Regarding drinking water, the majority of girls were drunk more than 1.5 liter $55.30 \%$, while about $44.70 \%$ of them were drunk less than 1.5 liter. The girls reported that $57.3 \%$ of them consumed fried foods $70 \%$, while $76.0 \%$ of them consumed sweets. As for preferred cooking method, the majority of subjects were preferred $59.66 \%$, while about $6.66 \%$ of them were preferred traditional (Mesabek) methods. 
Table (6) shows lifestyle of the study sample, the total number of study participants amounted to 300 female adolescents; the percentages of female adolescents who have physical exercise $82.33 \%$ of them, while about $17.67 \%$ of them were not practice. As for types of physical exercises were $55.46 \%$ of them practiced light activities, and $42.52 \%$ of them practiced moderate activities, and $2.02 \%$ of them practiced vigorous activities. Time of physical exercises were $65.58 \%$ of them practiced less than 30 minutes, and $23.90 \%$ of them practiced between 30 to 60 minutes, and $10.52 \%$ of them practiced than 60 minutes. Female adolescents seem to watch TV was $52.0 \%$ for two hours, while $20.0 \%$ of them watching more than 6 hours.

Table (7) shows Dietary awareness questions which were requested in the study sample, as shown 20 questions for nutritional awareness were directed to female adolescents; it were as follows: What are the components of the full diet?, For a healthy diet should be consuming?, Aspects of good nutrition?, The most important primary energy sources?, To maintain the activity and safety of the body?, Drinking water frequently necessary for?, Of foods that work to build and renew the body's cells?, What of the following foods provide the body with protein?, There are abundant in fiber?, Of the most important sources of vitamins and minerals?, Vegetables rich in vitamins?, Iron deficiency lead to?, Zinc is important for?, There is an abundance of calcium?, The symptoms of anemia?, Enters in the composition of bone?, The symptoms of vitamin B deficiency?, Vitamin A is important for?, Lack of vitamin in D in food causes illness?, and Uses of vitamin C. The correct answer ratios were differed among themselves as shown in the table.

Table (8) shows dietary awareness level in the study sample, the most of female adolescents $52.5 \%$ have middle level of dietary awareness, while $38.1 \%$ of them have high level of dietary awareness, and finally $9.4 \%$ of them have low level of dietary awareness, with mean value $11.40 \pm 4.52$ correct answer/questions for all study sample.

Table (9) shows correlation matrix between health state and anthropometric, food habits in the study sample, there is a statistically 
significant relationship between health state and weight, also body mass index at $(\mathrm{P}<0.05)$ and there is a statistically significant relationship between health state and food habits at $(\mathrm{P}<0.01)$.

Table (10) shows correlation matrix between nutritional degree and health state ,socio factors in the study sample, there is a statistically significant relationship between nutritional degree and health state at $(\mathrm{P}$ $<0.01$ ), also there is a statistically significant relationship between nutritional awareness degree and family income, mother's education, father's education, working mother and working father at $(\mathrm{P}<0.05)$.

Table (11) shows correlation matrix between nutritional awareness degree and anthropometric measurements in the study sample, there is no a statistically significant relationship between nutritional awareness degree and anthropometric measurements (Weight, Height, and Body mass index).

\section{Discussion:}

The main age of the studied female adolescents was $14.33 \pm 1.11$ years about $52 \%$ of had normal weight BMI, these results is in a concordance with those studies in Jeddah province, Saudi Arabia, which revealed that the main age of the studied adolescents was $14.2 \pm 0.9$ for female adolescents. About $50 \%$ of female had underweight BMI, it was noticed that $30 \%$ were normal weight for BMI (Alkoly et al., 2011).

Our study revealed that the prevalence of obesity and overweight is $11.7 \%$ and $7.6 \%$ respectively (19.3\%). These results is in a concordance with those studies in the Eastern province Al-Hasaa, Kingdom of Saudi Arabia, which revealed that the combined prevalence of obesity and overweight was (23.9\%) (Amin et al., 2008), which had the highest prevalence compared to other studies in KSA (El Hazmi et al., 2002). While another school- based survey in the Kingdom revealed that the overall prevalence of overweight was $11.7 \%$ and obesity was $15.8 \%$ (combined prevalence of obesity and overweight $27.5 \%$ ) among the included subjects aged 6-18 years. Also Alkoly et al., (2011) revealed that the combined prevalence of obesity and overweight is equal at $27.1 \%$ in both genders from adolescents. 
As for lifestyle of the percentages of female adolescents who have physical exercise $82.33 \%$ of them, while about $55.46 \%$ of them practiced light activities. $65.58 \%$ of them practiced less than 30 minutes. In general, our adolescents exercise is less than those in developed countries (Kann et al., 2000) this may be due to inadequate school physical activity programs for these students. Lack of regular physical activity constitutes a major risk factor for cardiovascular disease (Grundy et al., 1997). Encouraging adolescents into a sustainable active lifestyle will influence the incidence of adult heart disease and stroke in the future (Walton et al., 1999).

In the recent years, with the huge advances in technology and improved living standards, the overall energy intake has increased due to over nutrition. On the other hand, lifestyle is becoming more and more sedentary and energy expenditure is reduced. Our study supported that concept. The apparent differences in the rates observed from different studies carried out in different parts of KSA may be partly attributed to different socioeconomic status of the study samples, science social class is a pre- cursor to nutritional habit which is a risk factor for overweight and obesity. In addition to different socio-economic status, ethics and genetic difference may account for the variations in the prevalence of obesity between American and Saudi adolescents (Al-Rukban et al., 2003).

Our study revealed that female adolescents seem to watch TV was $52.0 \%$ for two hours, while $20.0 \%$ of them watching more than 6 hours. These results may explained that about $52 \%$ of girls had normal weight BMI, while Alkoly et al., (2011) showed that $41.4 \%$ of female adolescents spent $>6$ hours watching TV. These result concur with the result of Roberts et al. (2005), American youths spend 6.5 hours per day or 44.5 hours per week with media. Almost 4 hours per day listening to radio or recorded music, and 45 minutes per day reading magazines or books (not for school).

Our results revealed that the most of female adolescents were enrolled at the third grade year $43.7 \%$. Mothers ' Middle / Secondary educations were among females by $37.7 \%$, while father's university education was $34.3 \%$ and $58.5 \%$, respectively. Furthermore, the percentage of working fathers was $61.1 \%$ as government employee, as for working mothers was $66.67 \%$ was unemployed and the majority of the sample family sizes were $58.30 \%$ 
$\overline{\underline{ }}$

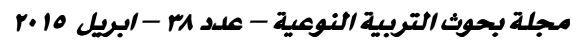

from 6 to 9. Moreover, the majority of students 35.3\% had high family income more 6000 to 10000 Saudi Riyal, while $14.7 \%$ of them had low family income between 1000 to 3000 SR.

The results showed that $84.3 \%$ of female adolescents were not suffering from diseases, while about $15.7 \%$ of them were suffering from diseases $48.90 \%$ of them were suffering from anemia. Iron-deficiency anemia is the most common nutritional deficiency noted among children and adolescents. Several risk factors are associated with its development among adolescents, including rapid growth, inadequate dietary intake of iron-rich foods or foods high in vitamin $\mathrm{C}$, highly restrictive vegetarian diets, calorie-restricted diets, meal skipping, participation in strenuous or endurance sports, and heavy menstrual bleeding (Story et al., 2002 and Centers for Disease Control and Prevention,2002).

The results showed that there is a statistically significant relationship between health state and weight, also body mass index and there is a statistically significant relationship between health state and food habits. Also there is a statistically significant relationship between nutritional degree and health state also there is a statistically significant relationship between nutritional awareness degree and family income, mother's education, father's education, working mother and working father. Wronka (2013) he found that Socioeconomic differences in BMI were increase with age. Parents' higher education was associated with smaller BMI gain between the ages of 7 and 18 years. Mother and/or father had higher education the prevalence of underweight increased with age.

The results illustrated that the majority of female adolescents reported eating three meals daily $54 \%$, and about $28.33 \%$ of them reported eating two meals daily, while the majority of female adolescents reported deleted the breakfast meal about $41.0 \%$,. It is clear from table (5) the majority of girls reported eating breakfast $51.70 \%$, and about $48.30 \%$ of them did not reported eating breakfast. Regardless of the regular consumption of breakfast, Niklas et al., (2001) argued that regular consumption of breakfast may control body weight due to the decrease in fat content in the diet because of the role it plays in minimizing the intake of high energy snacks. 
Regarding preferred foods, the majority of girls were preferred soft drinks $33 \%$, while about $8.3 \%$ of them were preferred nuts. The majority of girls reported drinking tea $70 \%$, and about $30 \%$ of them did not drinking in the present study agrees with the study of El-Dosokey (2006) who reported that the adolescent girls individuals who drink tea immediately were $34.7 \%$. Also Habeeb (2008) study adolescent girls who deal drinks with sugar reported that the number of tea- spoon of sugar about one, two, three and over recorded $(6.0,32.0,56.0$ and $6.0 \%)$ respectively. The girls reported that $57.3 \%$ of them consumed fried foods $70 \%$, while $76.0 \%$ of them consumed sweets. As for preferred cooking method, the majority of subjects were preferred $59.66 \%$, while about $6.66 \%$ of them were preferred traditional (Mesabek) methods. Alkoly et al., (2011) reported that the mean food intake of adolescents in comparison to the recommended daily dietary allowances was high. Also eating behaviors for intermediate schools still require development.

A better understanding of adolescent's diet and eating behaviors is essential for relevant education and intervention programs. Additionally, enquiry tools specifically designed for adolescents are direly needed. The enquiry should encompass household food security, food diversity (as an indicator of nutritional quality), eating practices and underlying influences, and physical activity. These tools need to be developed and validated in different settings, in connection with school based or health center based intervention programs rather than as free standing research.

It could be concluded from the results that dietary awareness level in the study sample, the most of female adolescents $52.5 \%$ have middle level of dietary awareness,. These results are in agreement with Simopoulos, (1985) who reported that nutrition knowledge about composition of a balanced diet are tissue building and protective groups of food. The nutritional problems in Saudi Arabia are mainly due to a change in food habits, illiteracy and ignorance, rather than a shortage of food supply or low income. Therefore, it is essential for all people to eat a balanced diet which will provide the dietary requirements of all nutrients. Perhaps behavior modification with respect to food intake will be effective in the treatment of underweight (Simopoulos, 1985). 


\section{CONCLUSION}

In conclusion, the study found that high percentage of female adolescent hade a middle degree of nutritional awareness and dietary knowledge. This finding is similar to other studies done in the kingdom in different cities, but there was no response. So this will enhance health authorities to create program to upraise the nutritional awareness of the community for this important stage, especially at primary health care levels and at school.

\section{RECOMMENDATIONS}

This study recommended to the importance of raising awareness of food among teenagers, because of its positive effects to change some beliefs and habits inherited misconceptions. Stay nutrition education workshops for teenagers diet patrol through the institutions concerned.

Table (1): Epidemiological features of studied sample $(\mathrm{n}=300)$

\begin{tabular}{|c|c|}
\hline Mean \pm SD & Variables \\
\hline \hline $14.33 \pm 1.11$ & Age in years \\
\hline $47.71 \pm 10.86$ & Weight in $\mathrm{Kg}$ \\
\hline $150.86 \pm 7.45$ & Height in cm \\
\hline $20.82 \pm 4.12$ & Body Mass Index \\
\hline $24.33 \pm 2.71$ & Arm Circumference cm \\
\hline
\end{tabular}

Table (2): Distribution of the study sample $(\mathrm{n}=300)$ according to BMI

\begin{tabular}{||c|c|c||}
\hline \hline Percent $\%$ & Frequency & Body mass index BMI classification $(\mathrm{kg} / \mathrm{m} 2)$ \\
\hline \hline 28.7 & 86 & Underweight $(\geq 5$ th percentile $)$ \\
\hline 52.0 & 156 & Normal weight $($ from 5 th to $<85$ th percentile $)$ \\
\hline 11.7 & 35 & Overweight $(85$ th to $<95$ th percentile $)$ \\
\hline 7.6 & 23 & Obesity $(\leq 95$ th percentile $)$ \\
\hline 100 & 300 & Total \\
\hline
\end{tabular}


Table (3): Demographic characteristic of the study sample $(n=300)$

\begin{tabular}{|c|c|c|}
\hline Percent\% & Frequency & Variables \\
\hline \multicolumn{3}{|c|}{$\overline{\text { School grades }}$} \\
\hline 23.0 & 69 & 1st grade \\
\hline 26.3 & 79 & 2nd grade \\
\hline 43.7 & 131 & 3rd grade \\
\hline 7.0 & 21 & not answers \\
\hline 100 & 300 & Total \\
\hline \multicolumn{3}{|c|}{ Mother's Education } \\
\hline 23 & 69 & Illiterate / Primary \\
\hline 37.7 & 113 & Middle / Secondary \\
\hline 32.0 & 96 & University \\
\hline 7.3 & 22 & High college level \\
\hline 100 & 300 & Total \\
\hline \multicolumn{3}{|c|}{ Father's Education } \\
\hline 18.0 & 54 & Illiterate / Primary \\
\hline 34.3 & 103 & Middle / Secondary \\
\hline 34.3 & 103 & University \\
\hline 13.3 & 40 & High college level \\
\hline 100 & 300 & Total \\
\hline \multicolumn{3}{|c|}{ Working Mother } \\
\hline 28.7 & 68 & Government employee \\
\hline 4.7 & 14 & Private sector employee \\
\hline 66.67 & 200 & Unemployed \\
\hline 100 & 300 & Total \\
\hline \multicolumn{3}{|c|}{ Working Father } \\
\hline 61.1 & 183 & Government employee \\
\hline 23.3 & 70 & Private sector employee \\
\hline 15.6 & 47 & Unemployed \\
\hline 100 & 300 & Total \\
\hline \multicolumn{3}{|l|}{ Family size } \\
\hline 22.0 & 66 & $3-5$ \\
\hline 58.30 & 175 & $6-9$ \\
\hline 19.70 & 59 & More than 10 \\
\hline 100 & 300 & Total \\
\hline \multicolumn{3}{|c|}{ Family Income/SR } \\
\hline 14.7 & 44 & Low $(1000-3000)$ \\
\hline 30.7 & 92 & Intermediate $(>3000-6000)$ \\
\hline 35.3 & 109 & High $(>6000-10000)$ \\
\hline 18.3 & 55 & Very high $(>10000)$ \\
\hline 100 & 300 & Total \\
\hline
\end{tabular}




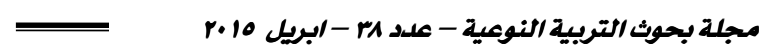

Table (4): Health state of the study sample $(n=300)$

\begin{tabular}{|c|c|c|}
\hline Percent $\%$ & Frequency & Variables \\
\hline \multicolumn{3}{|c|}{ Suffering from diseases } \\
\hline 15.7 & 47 & Yes \\
\hline 84.3 & 253 & No \\
\hline 100 & 300 & Total \\
\hline \multicolumn{3}{|c|}{ Types of disease } \\
\hline 48.90 & 23 & Anemia \\
\hline 21.50 & 10 & Gastrointestinal diseases \\
\hline 8.30 & 4 & Hypertension \\
\hline 6.50 & 3 & Liver diseases \\
\hline 8.30 & 4 & Diabetes mellitus \\
\hline 6.50 & 3 & Cardiovascular disease \\
\hline 100 & 47 & Total \\
\hline \multicolumn{3}{|c|}{ Taking medications } \\
\hline 25.3 & 76 & Yes \\
\hline 74.7 & 224 & No \\
\hline 100 & 300 & Total \\
\hline \multicolumn{3}{|c|}{ Medications types } \\
\hline 42.20 & 32 & Sedatives \\
\hline 32.70 & 25 & Antibiotics \\
\hline 2.60 & 2 & Hypertension drugs \\
\hline 5.20 & 4 & Diabetic drugs \\
\hline 17.30 & 13 & Others \\
\hline 100 & 76 & Total \\
\hline \multicolumn{3}{|c|}{ Taking dietary supplements } \\
\hline 23.7 & 71 & Yes \\
\hline 76.3 & 229 & No \\
\hline 100 & 300 & Total \\
\hline
\end{tabular}


Effect of Food Habits and Nutritional Awareness on Body Mass Index and Health Status

Table (5): Food habits of the study sample $(n=300)$

\begin{tabular}{|c|c|c|}
\hline Percent $\%$ & Frequency & Variables \\
\hline \multicolumn{3}{|c|}{ Number of meals daily } \\
\hline 8.34 & 25 & One meal \\
\hline 28.33 & 85 & Two meal \\
\hline 54 & 162 & Three meal \\
\hline 9.33 & 28 & $\leq$ Four \\
\hline 100 & 300 & Total \\
\hline \multicolumn{3}{|c|}{ Delete of meals Intake } \\
\hline 41.0 & 152 & Breakfast \\
\hline 16.0 & 48 & Lunch \\
\hline 20.30 & 61 & Dinner \\
\hline 22.70 & 68 & No \\
\hline 100 & 300 & Total \\
\hline \multicolumn{3}{|c|}{ Eating breakfast } \\
\hline 51.70 & 155 & Yes \\
\hline 48.30 & 145 & No \\
\hline 100 & 300 & Total \\
\hline \multicolumn{3}{|c|}{ Preferred foods } \\
\hline 33 & 99 & Soft drinks \\
\hline 8.3 & 25 & Nuts \\
\hline 30 & 90 & Fruit juice \\
\hline 23.7 & 71 & Chocolate \\
\hline 31 & 93 & Chips and snacks \\
\hline \multicolumn{3}{|c|}{ Drinking tea } \\
\hline 70 & 210 & Yes \\
\hline 30 & 90 & No \\
\hline 100 & 300 & Total \\
\hline \multicolumn{3}{|c|}{ Drinking water more than 1.5 liter } \\
\hline 55.30 & 166 & Yes \\
\hline 44.70 & 134 & No \\
\hline \multirow[t]{2}{*}{100} & 300 & Total \\
\hline & & Fried foods \\
\hline 57.3 & 172 & Yes \\
\hline 42.7 & 128 & No \\
\hline \multirow[t]{2}{*}{100} & 300 & Total \\
\hline & & Sweets consumption \\
\hline 76.0 & 228 & Yes \\
\hline 24.0 & 72 & No \\
\hline 100 & 300 & Total \\
\hline \multicolumn{3}{|c|}{ Preferred cooking method } \\
\hline 6.66 & 20 & Traditional (Mesabek) \\
\hline 18.34 & 55 & Boiled or stir-fried \\
\hline 59.66 & 179 & Grilled \\
\hline 15.34 & 46 & Baking \\
\hline 100 & 300 & Total \\
\hline
\end{tabular}




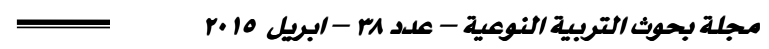

Table (6): Lifestyle of the study sample $(n=300)$

\begin{tabular}{|c|c|c|}
\hline Percent $\%$ & Frequency & Variables \\
\hline \multicolumn{3}{|c|}{ Physical exercises } \\
\hline 82.33 & 247 & Yes \\
\hline 17.67 & 53 & No \\
\hline 100 & 300 & Total \\
\hline \multicolumn{3}{|c|}{ Types of physical exercises } \\
\hline 55.46 & 137 & Light activities \\
\hline 42.52 & 105 & Moderate activities \\
\hline 2.02 & 5 & Vigorous activities \\
\hline 100 & 247 & Total \\
\hline \multicolumn{3}{|c|}{ Time of physical exercises } \\
\hline 65.58 & 162 & $<30$ min. \\
\hline 23.90 & 59 & $\leq 30-60 \mathrm{~min}$ \\
\hline 10.52 & 26 & $>60 \mathrm{~min}$ \\
\hline 100 & 247 & Total \\
\hline \multicolumn{3}{|c|}{ Number of watching T.V. hours } \\
\hline 52.0 & 156 & Two \\
\hline 28.0 & 84 & Four \\
\hline 20.0 & 60 & More than six \\
\hline 100 & 300 & Total \\
\hline
\end{tabular}


= Effect of Food Habits and Nutritional Awareness on Body Mass Index and Health Status

Table (7): Nutritional awareness questions which were requested in the study sample $(\mathrm{n}=300)$

\begin{tabular}{|c|c|c|c|c|}
\hline \multicolumn{2}{|c|}{ Wrong answer } & \multicolumn{2}{|c|}{ Correct answer } & \multirow[t]{2}{*}{ Questions } \\
\hline Percent $\%$ & Frequency & Percent $\%$ & Frequency & \\
\hline 46.67 & 140 & 53.33 & 160 & What are the components of the full diet? \\
\hline 23.34 & 70 & 76.66 & 230 & For a healthy diet should be consuming? \\
\hline 4.67 & 14 & 95.33 & 286 & Aspects of good nutrition? \\
\hline 7.67 & 33 & 92.33 & 277 & The most important primary energy sources? \\
\hline 30 & 90 & 70 & 210 & $\begin{array}{l}\text { To maintain the activity and safety of the } \\
\text { body? }\end{array}$ \\
\hline 20 & 60 & 80 & 240 & Drinking water frequently necessary for? \\
\hline 74.34 & 223 & 25.66 & 77 & $\begin{array}{l}\text { Of foods that work to build and renew the } \\
\text { body's cells? }\end{array}$ \\
\hline 11.34 & 34 & 88.66 & 266 & $\begin{array}{l}\text { What of the following foods provide the body } \\
\text { with protein? }\end{array}$ \\
\hline 43 & 129 & 57 & 171 & There are abundant in fiber? \\
\hline 60 & 180 & 40 & 120 & $\begin{array}{l}\text { Of the most important sources of vitamins } \\
\text { and minerals? }\end{array}$ \\
\hline 66.34 & 199 & 33.66 & 101 & Vegetables rich in vitamins? \\
\hline 57.34 & 172 & 42.66 & 128 & Iron deficiency lead to? \\
\hline 68.34 & 205 & 31.66 & 95 & Zinc is important for? \\
\hline 36.34 & 109 & 63.66 & 191 & There is an abundance of calcium? \\
\hline 54.67 & 164 & 45.33 & 136 & The symptoms of anemia? \\
\hline 47.34 & 142 & 52.66 & 158 & Enters in the composition of bone? \\
\hline 70.34 & 211 & 29.66 & 89 & The symptoms of vitamin B deficiency? \\
\hline 70.67 & 212 & 29.33 & 88 & Vitamin A is important for? \\
\hline 40 & 120 & 60 & 180 & Lack of vitamin in D in food causes illness? \\
\hline 26.67 & 80 & 73.33 & 220 & Uses of vitamin C? \\
\hline
\end{tabular}


Table (8): Nutritional awareness level in the study sample $(\mathrm{n}=300)$

\begin{tabular}{|c|c|c||}
\hline Percent\% & Frequency & Nutritional awareness level \\
\hline \hline 38.1 & 114 & High (less $60 \%)$ \\
\hline 52.5 & 158 & Middle $(60 \%-79.9 \%)$ \\
\hline 9.4 & 28 & Low (more $80 \%)$ \\
\hline 100 & 300 & Total \\
\hline \multicolumn{2}{|c|}{$11.41 \pm 4.52$} & Mean \pm SD \\
\hline
\end{tabular}

Table (9): Correlation matrix between health state and anthropometric measurements, food habits

\begin{tabular}{||c|c|c|c|c|c||}
\hline \multirow{3}{*}{$\begin{array}{c}\text { Health } \\
\text { state }\end{array}$} & Correlation & Weight & Height & $\begin{array}{c}\text { Body mass } \\
\text { index BMI }\end{array}$ & Food habits \\
\cline { 2 - 6 } & Pearson & $--0.157^{*}$ & $-0.021^{*}$ & $-0.157^{*}$ & $-0.144^{* *}$ \\
& $\begin{array}{c}\text { correlation } \\
\end{array}$ & 0.025 & 0.024 & 0.033 & 0.016 \\
\hline
\end{tabular}

* correlation is significant at the 0.05 level (2-tailed).

** Correlation is significant at the 0.01 level (2-tailed).

Table (10): Correlation matrix between dietary awareness degree and Socio factors

\begin{tabular}{||c|c|c|c|c|c|c|c||}
\hline \multirow{2}{*}{$\begin{array}{c}\text { Nutritional } \\
\text { degree }\end{array}$} & Correlation & $\begin{array}{c}\text { Health } \\
\text { state }\end{array}$ & $\begin{array}{c}\text { Family } \\
\text { income }\end{array}$ & $\begin{array}{c}\text { Mother's } \\
\text { Education }\end{array}$ & $\begin{array}{c}\text { Father's } \\
\text { Education }\end{array}$ & $\begin{array}{c}\text { Working } \\
\text { mother }\end{array}$ & $\begin{array}{c}\text { Working } \\
\text { father }\end{array}$ \\
\cline { 2 - 9 } & $\begin{array}{c}\text { Pearson correlation } \\
\text { Sig. (2-tailed) }\end{array}$ & $-0.012 * *$ & $-0.079 *$ & $-0.015^{*}$ & $-0.079 *$ & $-0.052 *$ & $-0.059 *$ \\
& 0.063 & 0.058 & 0.013 & 0.043 & 0.056 & 0.028 \\
\hline
\end{tabular}

* Correlation is significant at the 0.05 level (2-tailed).

** Correlation is significant at the 0.01 level (2-tailed).

Table (11): Correlation matrix between nutritional awareness degree and anthropometric measurements

\begin{tabular}{||c|c|c|c|c||}
\hline \multirow{2}{*}{$\begin{array}{c}\text { Nutritional } \\
\text { degree }\end{array}$} & Correlation & Weight & Height & Body mass index BMI \\
\cline { 2 - 5 } & Pearson correlation & -0.031 & -0.154 & -0.021 \\
& Sig. (2-tailed) & 0.332 & 0.053 & 0.758 \\
\hline
\end{tabular}

* Correlation is significant at the 0.05 level (2-tailed). 


\section{References:}

- Alkoly, T. A., Asmaa, M. A., and Alghamidi, A.K., (2011): Nutritional Status and Eating Behaviors among Adolescents of Some Intermediate Schools in Jeddah, JKAU: Med. Sci., Vol. 18 No. 2, pp: xx- xx (2011 A.D. / 1432 A.H.) DOI: 10.4197/Med. 18-2.X.

- Al-Rethaiaa, A.S., Fahmy, A.E., Al-Shwaiyat, N.M. (2010): Obesity and eating habits among college students in Saudi Arabia: A cross sectional study. Nutr J.9:39..7.

- Al-Rukban, M.O. (2003): Obesity among Saudi male adolescents in Riyadh, Saudi Arabia. Saudi Med J; 24(1): 27-33.

- Amin, T.T., Al-Sultan, A.I., Ali, A.(2008): Overweight and obesity and their association with dietary habits and sociodemographic characteristic among male primary school children in Al- Hassa, Kingdom of Saudi Arabia. Indian J Community Med; 33(3). 172181.

- Asmaa, T.Y. (2011): The Role of Nutritional Education in Raising Awareness and Information Among Students in The Preparatory Phase. M-SC. In nutrition and food sciences, Faculty of Home Economics Menoufia University, Egypt.

- Bellizzi, M.C., Dietz, W.H.(1999): Workshop and Childhood obesity, summery of the discussion. Am J Clin Nutr; 70(1): 173S-175S.

- Centers for Disease Control and Prevention (2002): Recommendation to prevent and control iron deficiency anemia in the United States Morb Mortal Wkly rep; 51(40). 897-99.

- El Hazmi, M.A., Warsy, A.S.(2002): The prevalence obesity and overweight in 1-18 year old Saudi children. Ann Saudi Med; 22(5-6): 202-207.

- El-Dosokey,I.W. (2006): The use of nutrition education in improving the nutritional status of children in orphanages.M-SC. In nutrition and food sciences, Faculty of Home Economics Menoufia University, Egypt.

- Forbes, G.R. (1992):Nutrition and growth. In: McAnarney ER, Kreipe RE, Orr DP, Comerci GD, eds. Textbook of adolescent medicine. Philadelphia: WB Saunders;68-74.

- Greer FR, Krebs NF. Optimizing bone health and calcium intakes of infants, children, and adolescents. PEDIATRICS. Feb 2006;117(2):578-585. 
- Grundy, S.M., Balady ,G.J., Criqui, M.H., Fletcher, G., Greenland, P., Hiratzka, L.F., Houston- Miller, N., Kris-Etherton, P., Krumholz, H.M., LaRosa, J., Ockene, I.S., Pearson, T.A., Reed, J., Washington, R., and Smith, S.C. 1997): Guide to primary prevention of cardiovascular diseases. A statement for healthcare professionals from the Task Force on Risk Reduction. American Heart Association Science Advisory and Coordinating Committee. Circulation; 95(9): 2329-2331.

- Habeeb, M.R. (2008): Assessment the nutrition habits and influence on health status for Adolescences in some high school Ashmoon Menoufiya. M-SC. In nutrition and food sciences, Faculty of Home Economics Menoufia University, Egypt.

- Haerens, L., Craeynest, M., Deforche, B., Maes, L., Cardon, G., De Bourdeaudhuij, I.(2008): The contribution of psychosocial and home environmental factors in explaining eating behaviors in adolescents. Eur J Clin Nutr; 62(1): 51-59.

- Abalkhail, B., and Shawky, S. (2002): Comparison between body mass index, triceps skin fold thickness and mid-arm muscle circumference in Saudi adolescents. Ann Saudi Med; 22(5-6): 324-328.

- Kann, L, Kinchen, S.A., Williams, B.I., Ross, J.G., Lowry, R., Grunbaum, J.A.(2000): Youth risk behaviors surveillance. United States. J Sch Health; 70(7): 271-286.

- Kuczmarski, R.J., Ogden, C.L., Grummer-Strawnl, M., Flegal, K.M., Guoss, Wei. R.( 2000): CDC growth charts; United States. Advanced Data from Vital and Health Statistics No 314. Hyatts Ville, Maryland: National Center for Health Statistics.

- Mahan, L.K., Escott-Stump S (2008):. Krause's Food \& Nutrition Therapy. 12th ed. St. Louis, MO: Elsevier Saunders, 2008.

- Nicklas, T.A., Baranowski, T., Cullen, K.W., Berenson, G. (2001): Eating patterns, dietary quality and obesity. J Am Coll Nutr; 20(6): 599-608.

- Park, J.E., Park. (1979): Text Book of Preventive and Social Medicine; 7th ed. Hessers Barner Side Ph Riblisher.1268 Napier Town.pp: 81.

- Roberts, D.F., Foehr, U.G., Rideout, V. (2005): Generation M: Media in the Lives of 8-18 Year- Olds. Menlo Park, CA: Kaiser Family Foundation,. 7251. 
- Shang, L., O'Loughlin, J., Tremblay, A., and Gray- Donald K.(2014): The association between food patterns and adiposity among Canadian children at risk of overweight. Appl Physiol Nutr Metab. Feb;39(2):195-201.

- Shirur, R.R. (2000): Reproductive and Sexual Health Education for Adolescents Needs and Assessment. New Delhi: Discovery Publishing House.

- Simopoulos, A.P. (1985). Fat intake, obesity, and cancer of the breast and endometrium. Med Oncol Tumor Pharmacother;2:125-35.

- SPSS. (1998). Statistical package for social science computer software, ver 16.0.

- Stang, J., Story. M., eds.( 2005): Guidelines for Adolescent Nutrition Services. Minneapolis, MN: Center for Leadership, Education and Training in Maternal and Child Nutrition, Division of Epidemiology and Community Health, School of Public Health, University of Minnesota.

- Story, M.91992): Nutritional requirements during adolescence. In: McAnarney ER, Kreipe RE, Orr DE, Comerci GD, eds. Textbook of adolescent medicine. Philadelphia: WB Saunders;75-84. 2.

- Story, M., Holt, K., and Sofka, D.(2002): Bright futures in practice. Nutri. Arlington,Va: National Center For Education In Maternal And Child Health .

- Walton, J., Hoerr, S., Heine, L., Frost, S., Roisen, D., and Berkimer, M.( 1999): Physical activity and stages of change in fifth and sixth grades. J Sch Health; 69(7): 285-289.

- WHO Child and Adolescent health.( 2007): the work of WHO in the western pacific region, 08.

- World Health Organization.( 1995): The Use and Interpretation of Anthropometry: Report of WHO Expert Committee. WHO Team Rep Ser. 854: 1452.

- Wronka, I.( 2013): Socioeconomic status, body mass index and prevalence of underweight and overweight among polish girls aged 7-18: a longitudinal study. J Biosoc Sci. Jun ; 17:1-13. 
مجلة بحوث التربية النوعية - عدد rr - مبريل r.10

\section{تأثير العادات الغذائية والوعى الغذائى على هؤشر كتلة البسم}

\section{والحالة الصحية بين المراهقات فى المدارس المتوسطة بالمدينة المنورة}

إعداد

سها هاشم عبد الجواد

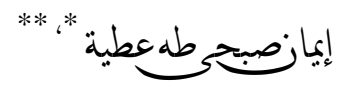

unill

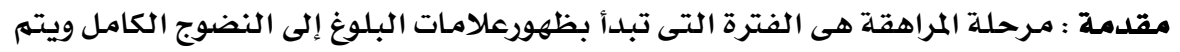

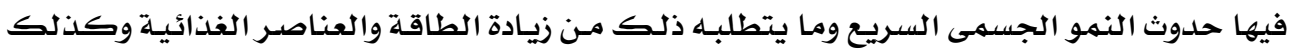

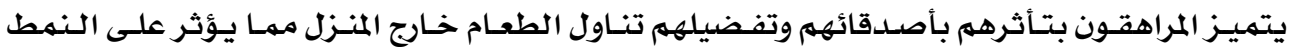

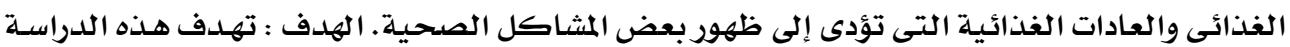

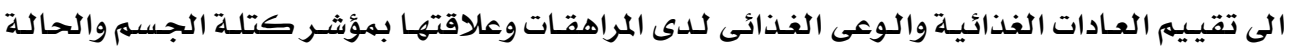

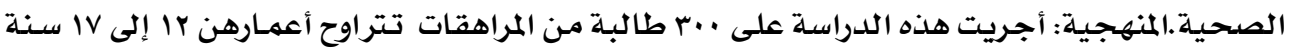

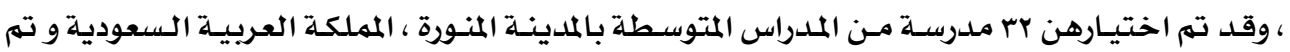

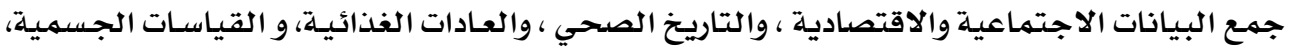

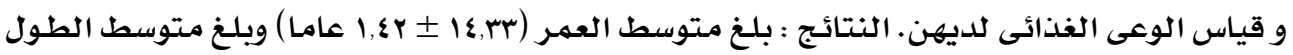

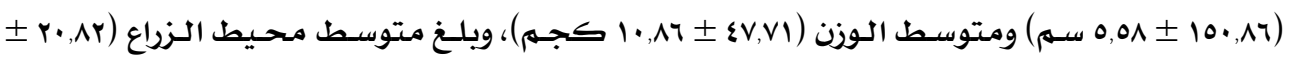

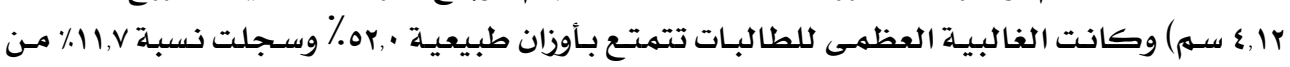

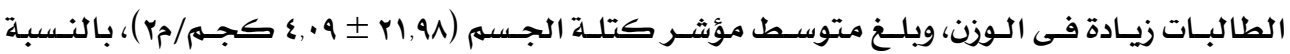

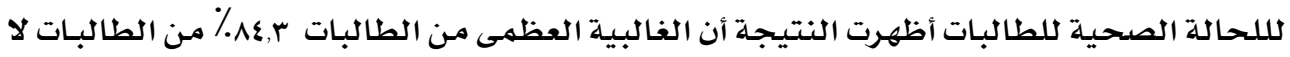

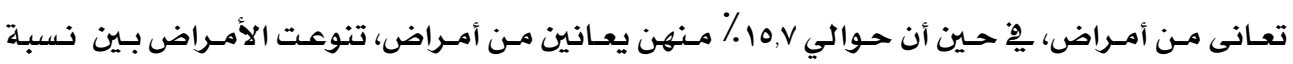

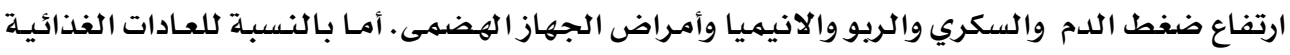

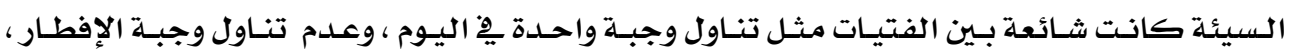

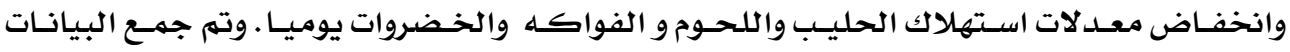

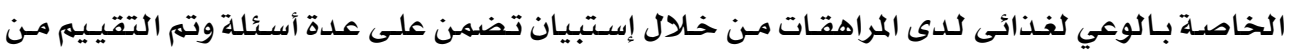

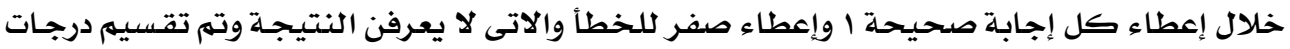

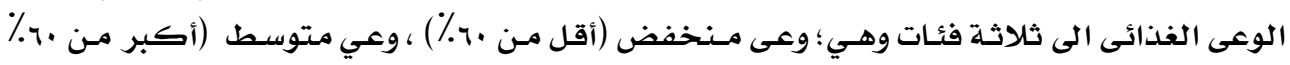

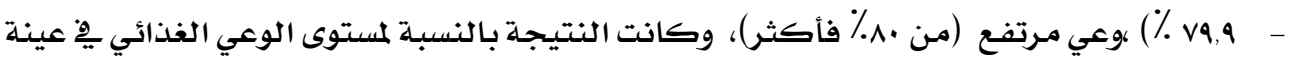

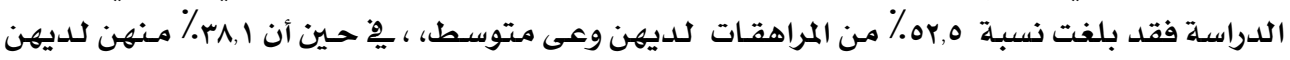




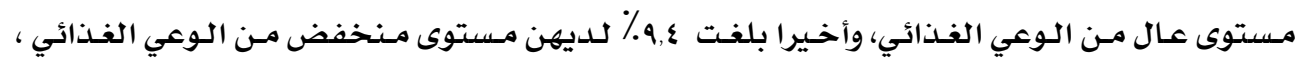

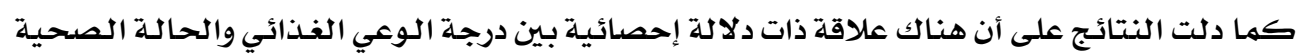

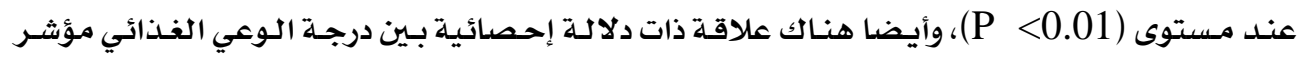

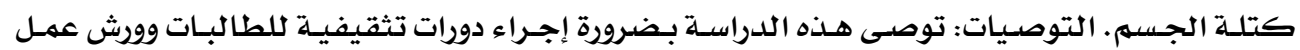

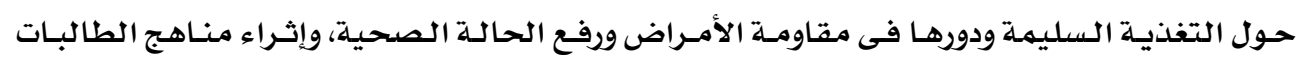

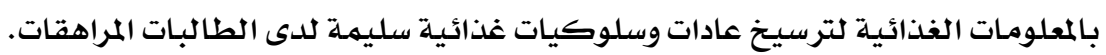

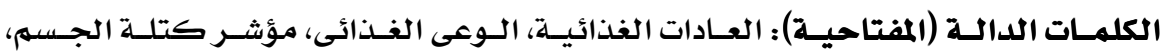

$$
\text { المراهقات، المدراس المتوسطة. }
$$

